\title{
A Literature Review on English Classroom Culture in China*
}

\author{
Xiaoli Ji, Jian Gong \\ Jiangsu University of Science and Technology, Zhenjiang, China \\ Email: jixiaoli2005@126.com
}

How to cite this paper: Ji, X. L., \& Gong, J. (2017). A Literature Review on English Classroom Culture in China. Open Journal of Modern Linguistics, 7, 263-271. https://doi.org/10.4236/ojml.2017.76019

Received: November 15, 2017

Accepted: December 22, 2017

Published: December 25, 2017

Copyright $\odot 2017$ by authors and Scientific Research Publishing Inc. This work is licensed under the Creative Commons Attribution International License (CC BY 4.0).

http://creativecommons.org/licenses/by/4.0/

\begin{abstract}
Classroom culture plays an important role in the studies on teaching, for it may serve as a theoretical tool with which researchers can explore into the invisible underlying forces that shape and govern the behavior of teachers and learners in the classroom. However, as a new theory or notion, the important of classroom culture haven't been recognized by the linguistics and teachers in China. This paper intends to provide a general introduction of English classroom culture in China through literature review. Influenced by educational tradition, Chinese teachers are supposed to conduct students academically and non-academically with him as a model while western teachers' role is to facilitate the communicative process between all participants in the classroom, and to act as an independent participant within the learning-teaching group. The influence of such a general understanding of the teacher roles upon English teaching is pervasive. For example, in dealing with the relationship of English teaching and learning, the teacher roles in teaching are stressed, while students' learning process and their roles are ignored. In summary, the teachers' and students' role in class and the boring class form are all the by-products of Chinese educational tradition. More measures should be taken to change English classroom culture in China.
\end{abstract}

\section{Keywords}

English Classroom Culture in China, Teachers' Role, Students' Role, Chinese Traditional Educational Principles

\section{Introduction}

The researches on language teaching used to focus on learners and learning *This paper is funded by research project of philosophy and social science in Jiangsu Province (Grant No. 2015SJB844), Social Science Foundation of Ministry of Education of China (Grant No. 15YJC740034), Applied Research Programs of Social Science Association of Jiangsu Province (17jsyw-02) and by funding of Jiangsu University of Science and Technology (WGYJG1606 (YB)). 
process while neglecting the social context and cultural elements. However, they begin to pay more and more attention to this perspective because they have been confronted with difficulties when they try to implement a new teaching methodology to the students from different backgrounds. In 1991, when introducing a special issue of Learning and Instruction on the theme of "Culture and Learning”, Roger Säljö (1991) suggested that there had been a paradigmatic shift in theorizing the sociocultural formation of human capabilities. He argued that culture could no longer be regarded as simply an outside influence on learning, because our patterns of social interaction, our understanding of the world, and our cognitive capacities are themselves culturally mediated and constituted. Classroom culture comes into being as a milestone in the history of second language acquisition and English language teaching because there are, in general, remarkably few references to cultural influence (Ellis, 1994).

Many people might doubt whether defining of the classroom is appropriate for they think it is just a spatial space for the students to learn knowledge (a language or something else). However, according to the educationalists' and anthropologists' point of view, the classroom is a social as well as a pedagogical reality (Tudor, 2001). As Gallego et al. (2001: p. 951) explain in their chapter entitled Classroom Cultures and Cultures in the Classroom, there is wide agreement that every continuing social group, such as the members of a classroom or workplace, develops a culture and set of social relationships that are peculiar and common to its members. Classroom culture may give us an insight into the teachers' and students' attitudes, beliefs, and expectations in the classroom.

The importance of studying classroom culture lies in that, it can provide educationalists with insights into the ways in which students perceive and interact with teachers. It provides principle for both teachers and students what sort of behavior is acceptable. Moreover, it will suggest the way of exploring how learning might be affected by the attitudes and expectations people bring to the learning situation. To conclude, the concept of classroom culture plays an important role in the studies on teaching, for it may serve as a theoretical tool with which researchers can explore into the invisible underlying forces that shape and govern the behavior of teachers and learners in the classroom.

\section{The English Classroom Culture in China}

According to Tudor (1996: p. 141), classroom culture "refers to the complex of attitudes and expectations which shape learners' sociocultural personality in the classroom, and thereby their interaction with their language study". That is to say, students' sociocultural personality in the classroom will influence their interaction with various aspects of language study. It involves learners' national or regional cultures. The concept of classroom culture encapsulates many of the beliefs and attitudes of the society in question, but they are perceived and experienced by the specific group of learners' concerned (Tudor, 1996: p. 141). Therefore, teachers' notion, students' behavior, and the class organization form 
are the representations of classroom culture.

\section{1) Teacher notion}

The principles measuring good teachers and students also serve as the rules governing classroom behavior, which is another presentation of particular classroom culture.

One of the most important researches about this problem is the one carried out by Cortazzi and Jin in 1993 among 15 highly experienced Western teachers of English working in Chinese universities. Based on the data provided by them, it is clearly illustrated that a teacher in China is the symbol of knowledge, which is entirely in keeping with the traditional Chinese notion that teaching is mainly to provide knowledge for students. Additionally, a good teacher is supposed to have moral character as the model, teaching students about the society and life. Thirdly, a good teacher is expected to be strict and fair, even like a parent with the moral role. Because of Chinese traditional culture of learning, a good student is supposed to be diligent in study first. From the part of paying attention to teachers, respecting and obeying them, a clear pattern of passive learning is obviously exemplified.

\section{2) Students' behavior}

The research carried out by Cortazzi and Jin in 1993 is mainly about the strong and weak points of Chinese culture of learning. "There is unanimous agreement that, on the positive side, Chinese students are diligent, persistent, thorough, and friendly. They are very good at memorizing." (Cortazzi \& Jin, 1996: pp. 184-185) In their paper, the students' behavior is summed as follows:

The students are not active in class, sitting there just to listen, unwilling to work in groups, and prefer whole-class work to individual work. Also students pay great attention to grades and exams but not to the processes of learning. They do not seem to be independent or open to alternative ideas (Cortazzi \& Jin, 1996). Besides, they find that Chinese students are passive about choosing a research topic because their criterion for choosing is based on the needs of lecturers and the department. They also exhibit dependent tendencies and expect to be guided step by step all the way in their learning, whereas their lecturers have very different conceptions about these matters.

Moreover, Chinese students ask fewer questions in class than Western students do. The questions they ask, which are proposed after sound reflection, may differ from Western students' spontaneous questions. "When students want to ask questions, they always think too much over it, whether it is worth asking or not." (Cortazzi \& Jin, 1996: p. 198)

Afterwards, a great amount of researches testify their propositions. Flowerdew and Miller (1995) cite lecturers', especially expatriate lecturers', frustration with students' reluctance to give their opinions, even when asked. Similarly, Song's (1995) experience of teaching reading to East Asian students in American universities illustrates their initial unease with group discussions and the extreme anxiety generated simply by the thought of asking a question in class.

But, this doesn't mean that there is no opponent opinion. Ngar-Fun Liu and 
William Littlewood (1996) make two large-scale investigations on university teachers and students in Hongkong which have provided some other perspectives. One of the most salient findings from their survey is that students prefer an active role. For example, their data show that the students enjoy group discussion most out of English activities (Table 1).

WHY ARE STUDENTS RELUCTANT TO PARTICIPATE?

Also the students like to do a lot of talking and to engage in pair or group work in class. Therefore, contrary to what Flowerdew and Miller (1995) believe, their survey results show that university students in Hong Kong do not adopt a negative, but a positive attitude towards participation in classroom discourse. Their results indicate clearly that students welcome opportunities (at least, in their English classes) for active participation at secondary as well as tertiary levels. This desire for active participation contrasts sharply with the passive role students are said to adopt.

So how can teachers labeled the students passive receivers while the students actually prefer a more active speech role in class?

One possible reason may be the mismatch between teachers' and students' perceptions of learner role. Not all forms of class participation are equally valued by students. According to the statistics from Ngar-Fun Liu and William Littlewood, when university teachers and students are asked to choose two features out of ten that they consider most important for successful spoken academic communication, they agree that unplanned, spontaneous speech is the most important. But teachers see the ability to raise appropriate questions or comments as the second most important aspect, whereas students see it as one of the least important. A similar contrast between the expectations of teachers and the performance of students was found in a study by Flowerdew and Miller (1992).

In view of the strong importance attached by students to oral communication ability, it may appear strange that "raising comments and questions" does not rank high in students' views of what is important for academic success. Since these views about the importance of raising comments and questions depend strongly on one's conception of the students' role in the learning process, here we can see the effects of an educational background which has socialized students into accepting a passive learning role which is not in agree with the teachers' notion and the methodologies they adopt in the classes.

\section{3) The class organization form}

The Intensive Reading Course is regarded as "the backbone of the English program" by Cortazzi and Jin (1996), for it is the premier language course car-

Table 1. Rank order of liking of English lesson activities in Forms 6 and 7.

\begin{tabular}{cc}
\hline Rank order of liking & English lesson activities \\
\hline $1^{\text {st }}$ & Group discussion \\
$2^{\text {nd }}$ & Watching video \\
$3^{\text {rd }}$ & Listening comprehension \\
\hline
\end{tabular}


ried out at all stages of English learning from school to university. It is a compulsory course using uniform syllabuses, textbooks, and final examinations at the school level. Therefore, observations from the Intensive Reading Course reflect the typical Chinese class organization form.

Despite its name, the Intensive Reading Course is designed or developed to use the text as a base for students to learn grammar and vocabulary by teachers' instruction. One example of this argument can be illustrated by Price (1979: p. 181). "Teachers studied the texts beforehand and selected what they variously described as teaching points or structure. ... A varied collection of inflections, idioms and phrases was thus gathered and ways devised to drill them."

$\mathrm{Wu}$ (1990) summarizes the main characteristics of the Intensive Reading Course as follows: The course enables students, first, to read the text aloud, or recite or paraphrase it with fairly good pronunciation. Secondly, it enables students to learn hundreds or thousands of vocabulary items with detailed explanations of meanings, and use the new words in exercises through blank filling, paraphrase, word formation and other methods. Thirdly, it requires the students to practice certain grammatical points exemplified in the text. Fourthly, as for the oral practice, it enables the students to speak on a limited range of subjects related to the text. Lastly, about writing and translating aspects, it requires the students to write generally correct sentences, short compositions and do translations based on the content and language of the text.

Briefly, the English class in China highly emphasizes the learning and use of grammar and vocabulary in a teacher-centered approach without much consideration of the students' communicative competence. It dominates both the guidelines, and the practice of English teaching in China. And it is not only the reason why the GT Method is so popular in our country but also why the Communicative Language Teaching has confronted many difficulties of implementation and operation in our country. The lack of culturally relevant pedagogy can only hinder learning. In the Kamehamha schools in Hawaii, native Hawaiian children were expected to takes turns telling narratives in a way that went against the lessons they learned through interactions in their homes where instead of one person telling a story, they collaboratively build a narrative in a story talk tradition $(\mathrm{Au}, 1980)$. As a result, when called upon to share during a sharing time, most students were reluctant to participate. It was culturally awkward and difficult to stand and individually narrate events. Additional examples such as differences in sharing time between working-class black children and white children and their middle-class counterparts are also documented by Shirley Brice-Heath (1983).

\section{A Comparison between Chinese and Western Classroom Cultures}

1) Different views of teachers' roles

A Chinese teacher is usually considered as a transmitter of knowledge, role, 
model, authority, and parent (Cortazzi \& Jin, 1996; Zhang, 2006). The primary roles of teachers in China are to teach books and educate students (师者, 所以 传道, 授业, 解惑也). Consequently, Chinese teachers are supposed to conduct students academically and non-academically with him as a model. The influence of such a general understanding of the teacher roles upon English teaching is pervasive. For example, in dealing with the relationship of English teaching and learning, the teacher roles in teaching are stressed, while students' learning process and their roles are ignored.

Opinions in the West on the teacher roles are very different. The teacher in the West generally has two main roles: to facilitate the communicative process between all participants in the classroom, and to act as an independent participant within the learning-teaching group. Other roles are needs as analyst, counselor, and group process manager.

Various opinions on teacher roles contribute to the formation of differences between Chinese and Western students' culture of learning, which shows a distinctive feature of independent thinking. Thus, Chinese students are more depend on their teachers, and lack of individual questions or opinions.

\section{2) Different views of students' roles}

In China the student is viewed as a passive receiver of knowledge. It is through accumulation of knowledge from books and the teachers that the student will become knowledgeable. Students are generally discouraged from expressing ideas in class and prohibited from speaking until allowed. The students are prone to look up to their teachers for direct guidance in any type of teaching activity.

The student in the West is seen as an active participant in English learning. The students are communicators, actively engaged in meaningful negotiation between the self, the learning process, and the object of learning. Attitudes towards student roles in class could influence their actual behavior directly. This is why Chinese students usually seem to play a role as a receiver in class, while western students appear to be the active participator in class.

\section{3) Different views of knowledge and learning}

To Chinese people, knowledge can be transmitted from the book to the reader or from one person to another. Learning is the process of acquiring such knowledge and teaching is the process of transmitting it. So the essential characteristics of English learning in Chinese are presented by memorization, repetition, and grammar or vocabulary exercises (Rao, 1996).

Western understanding of knowledge and learning shows different instructional beliefs. English is seen as a skill for the purpose of communication rather than a piece of knowledge to be stored in mind, that is to say, English learning is viewed as a skill development process.

The understanding of different views of knowledge and learning helps to clarify the explanation of foreign teachers' classroom activity organization, and their stress on fluency rather than accuracy in language class. 


\section{Theoretical Analysis}

What goes on within the classroom is influenced by factors within the general educational institution, the wider educational environment and the whole society. Classroom culture and culture of learning are cultivated phenomena in the educational field, because they are instructed by some traditional educational principles. Generally speaking, educationalists and researchers studying the Chinese culture of learning would probably go a step further and trace it to Confucianism, which is widely accepted as the traditional Chinese philosophy of education (Porter, 1983). Confucius, as an ancient educator, is supposed to establish Chinese educational tradition. Confucius encouraged students to ask questions, and then he responded with wisdom. He also proposed questions himself and then gave the answer. Therefore, Confucius acted as a messenger who transmitted his knowledge to his students, so he also set up his status as a respectable authority.

Chen (1990: p. 449) provides the teaching methods of Confucius. "The role of the teacher is to serve as a role model, to perfect virtue and assist in the development of talent, to answer questions, and to cultivate his own virtue and learning while encouraging students to do the same."

Flowerdew and Miller's (1995) research is about Confucian values in L2 lectures among Hong Kong Chinese who are studying English. The researchers discover that, according to the Confucian philosophy of education, teachers are expected to be the authority that is never questioned, and students are supposed to listen humbly and learn attentively in class.

Rao (1996) summarizes the impact of Confucius' teaching on foreign language teaching and learning in China as followings: first, concentration on intensive reading as a basis for language study; secondly, use of memorization and repetition learning as a basic acquisition technique; thirdly, emphasis on linguistic details and a corresponding lack of attention to communicative skills; fourthly, use of translation as both a teaching and a learning strategy; and fifthly, the prominence of the teacher's authority and the students' passive role. The above statement on Confucius educational philosophy helps to explain Chinese teachers' and students' attitudes and behavior in class.

To sum up with a comment from Lingenfelter (1999), the Confucian ethic expects teachers to be the authority who is never questioned, while Western students expect the lecturer to be a guide and facilitator, open to challenge. Confucian values may contrast with Western values as they relate to academics in the following dimensions (Lingenfelter, 1999).

\begin{tabular}{ll}
\hline \multicolumn{1}{c}{ Confucian values } & \multicolumn{1}{c}{ Western value } \\
\hline $\begin{array}{ll}\text { 1. Respect for the authority of lecturer } & \text { 1. Lecturer valued as a guide and facilitator } \\
\text { 2. Lecturer should not be questioned } & \text { 2. Lecturer is open to challenge } \\
\text { 3. Student motivated by family and pressure to } & \text { 3. Student motivated by desire for individual } \\
\text { excel } & \text { development } \\
\text { 4. Positive value placed on effacement and } & \text { 4. Positive value placed on self-expression } \\
\text { reticence } & \text { 5. Emphasis on individual development and } \\
\text { 5. Emphasis on group orientation to learning } & \text { creativity in learning }\end{array}$
\end{tabular}




\section{Conclusion}

Briefly, the teachers' and students' role in class and the boring class form are all the by-products of Chinese educational tradition. In the meanwhile, educational theories are built upon different traditional cultures. In sum, the impact of the process of learning and culture is mutual. There is no universal teaching methodology in the world for the learners of varied classroom cultures. We can't adopt a typical teaching methodology without regarding to the classroom culture. The cultural elements will play a more and more prominent role in the language learning and teaching process, which needs our attention and further studies. More measures should be taken to change English classroom culture in China.

\section{References}

Au, K. (1980). Participation Structures in a Reading Lesson with Hawaiian Children: Analysis of a Culturally Appropriate Instructional Event. Anthropology \& Education Quarterly, 11, 91-115. https://doi.org/10.1525/aeq.1980.11.2.05x1874b

Brice-Heath, S. (1983). Ways with Words. Cambridge, UK: Cambridge University Press.

Chen, J. (1990). Confucius as a Teacher: Philosopher of Confucius with Special Reference to Its Educational Implications. Beijing: Foreign Language Press.

Cortazzi, M., \& Jin, L. X. (1996). Cultures of Learning: Language Classrooms in China. In H. Coleman (Ed.), Society and the Language Classroom (pp. 169-206). New York: Cambridge University Press.

Ellis, R. (1994). The Strategy of Second Language Acquisition. Oxford: Oxford University Press.

Flowerdew, J., \& Miller, L. (1992). Student Perceptions, Problems and Strategies in Second Language Lecture Comprehension. RELC Journal, 23, 60-80. https://doi.org/10.1177/003368829202300205

Flowerdew, J., \& Miller, L. (1995). On the Notion of Culture in L2 Lectures. TESOL Quarterly, 29, 345-373. https://doi.org/10.2307/3587628

Gallego, M. A., Cole, M., \& The Laboratory of Human Cognition (2001). Classroom Cultures and Cultures in the Classroom. In V. Richardson (Ed.), Handbook of Research on Teaching (4th ed.). Washington DC: American Educational Research Association.

Lingenfelter, J. (1999). A Model for Understanding the Roles That Teachers Play in the Classroom. Ph.D. Dissertation, La Mirada, CA: Biola University.

Liu, N. F., \& Littlewood, W. T. (1996). Hong Kong Students and Their English. Hong Kong: Macmillan.

Porter, E. (1983). Foreign Teachers in China: Old Problems for a New Generation, 1979-1989. Westport, CT: Greenwood.

Price, R. F. (1979). Education in Modern China. London: Roultledge \& Kegan Paul.

Rao, Z. H. (1996). Reconciling Communicative Approaches to the Teaching of English with Traditional Chinese Methods. Research in the Teaching of English, 30, 458-471.

Säljö, R. (1991). Introduction: Culture and Learning. Learning and Instruction, 1, 179-185. https://doi.org/10.1016/0959-4752(91)90001-O

Song, B. (1995). What Does Reading Mean for East Asian Students? College ESL, 5, 35-48.

Tudor, I. (1996). Leaner-Centeredness as Language Education. New York: Cambridge 
University Press.

Tudor, I. (2001). The Dynamics of the Language Classroom. New York: Cambridge University Press.

Wu, Z. (1990). Reading with a Purpose-A Reassessment of the English Reading Programs Adopted in China. In Z. Wang (Ed.), ELT in China (pp. 78-90). Beijing: Foreign Language Teaching and Research Press.

Zhang, Q. (2006). Immediacy and Out-of-Class Communication: A Cross-Cultural Comparison. International Journal of Intercultural Relations, 30, 33-50.

https://doi.org/10.1016/j.ijintrel.2005.06.006 